\title{
BMJ Global Health Participatory and responsive governance in universal health coverage: an analysis of legislative provisions in Thailand
}

\author{
Aniqa Islam Marshall (D) , ${ }^{1}$ Kanang Kantamaturapoj, ${ }^{2}$ Kamonwan Kiewnin, ${ }^{1}$ \\ Somtanuek Chotchoungchatchai, ${ }^{1}$ Walaiporn Patcharanarumol, ${ }^{1,3}$ \\ Viroj Tangcharoensathien ${ }^{1}$
}

To cite: Marshall Al,

Kantamaturapoj K, Kiewnin K, et al. Participatory and responsive governance in universal health coverage: an analysis of legislative provisions in Thailand. BMJ Global Health 2021;6:e004117. doi:10.1136/ bmjgh-2020-004117

Handling editor Seye Abimbola

- Additional material is published online only. To view, please visit the journal online (http://dx.doi.org/10.1136/ bmjgh-2020-004117).

Received 6 0ctober 2020 Revised 25 January 2021 Accepted 26 January 2021

Check for updates

(C) Author(s) (or their employer(s)) 2021. Re-use permitted under CC BY-NC. No commercial re-use. See rights and permissions. Published by BMJ.

${ }^{1}$ International Health Policy Program, Ministry of Public Health, Nonthaburi, Thailand ${ }^{2}$ Faculty of Social Sciences and Humanities, Mahidol University, Salaya, Thailand

${ }^{3}$ Global Health Divsion, Ministry of Public Health, Nonthaburi, Thailand

Correspondence to Dr Viroj Tangcharoensathien; viroj@ihpp.thaigov.net

\section{ABSTRACT}

Participatory and responsive governance in universal health coverage (UHC) systems synergistically ensure the needs of citizens are protected and met. In Thailand, UHC constitutes of three public insurance schemes: Civil Servant Medical Benefit Scheme, Social Health Insurance and Universal Coverage Scheme. Each scheme is governed through individual laws. This study aimed to identify, analyse and compare the legislative provisions related to participatory and responsive governance within the three public health insurance schemes and draw lessons that can be useful for other low-income and middle-income countries in their legislative process for UHC. The legislative provisions in each policy document were analysed using a conceptual framework derived from key literature. The results found that overall the UHC legislative provisions promote citizen representation and involvement in $\mathrm{UHC}$ governance, implementation and management, support citizens' ability to voice concerns and improve UHC, protect citizens' access to information as well as ensure access to and provision of quality care. Participatory governance is legislated in 33 sections, of which 23 are in the Universal Coverage Scheme, 4 in the Social Health Insurance and none in the Civil Servant Medical Benefit Scheme. Responsive governance is legislated in 24 sections, of which 18 are in the Universal Coverage Scheme, 2 in the Social Health Insurance and 4 in the Civil Servant Medical Benefit Scheme. Therefore, while several legislative provisions on both participatory and responsive governance exist in the Thai UHC, not all schemes equally bolster citizen participation and government responsiveness. In addition, as legislations are merely enabling factors, adequate implementation capacity and commitment to the legislative provisions are equally important.

\section{BACKGROUND}

Responsive governance is one of the key goals for a health system, ${ }^{12}$ which requires public participation and engagement in decisionmaking to improve public services and patient satisfaction, increases utilisation and compliance to treatment, and overall contributing to better health outcomes and well-being of the

\section{Key questions}

What is already known?

- Participatory governance is a prerequisite for government responsiveness which aims to increase citizen participation in public policy processes which in turn increases responsive governance which aims to meet the health needs of citizens, and promote and improve access and quality of health services.

- Legislative provisions are enabling factors for responsive and participatory governance.

- Thailand's universal health coverage (UHC) has demonstrated exemplary outcomes in terms of service coverage, financial risk protection, pro-poor government subsidies and reduced under- 5 mortality gap.

What are the new findings?

- Legislative provisions in the Thai UHC promote both participatory and responsive governance.

- Each of the three public health insurance schemes in Thailand bolsters citizen participation and government responsiveness to citizens in varying degrees.

What do the new findings imply?

- The legislating of the 2002 National Health Security Act had involved citizens in the whole procedure, from the initiative process through the submission of a citizens' draft Act, to the second reading at the joint committee in the House of Representatives and the final adoption by consensus of all provisions related to participatory and responsive governance.

- Participatory governance and responsive governance legislated in UHC policies, as well as adequate implementation capacity and sustained commitment to the policies, are important in ensuring UHC meets citizen health needs and sustainable UHC.

population. ${ }^{34}$ According to the Declaration of Alma-Ata, "people have the right and duty to participate individually and collectively in the planning and implementation of their healthcare'. ${ }^{5}$ Participatory governance mechanisms facilitate citizen participation in public policy processes to increase citizen empowerment, 
promote deliberative democracy and ultimately bolster government responsiveness, accountability and transparency, leading to the provision of adaptive, resilient and people-centred public services. ${ }^{6}$ Several countries have implemented governance reforms in the health sector to increase citizen involvement in strategic decisions on health services and policies, and strengthen health governance, especially health system responsiveness to population needs. ${ }^{6-10}$ Outcome of these reforms have included increased government spending on health, propoor fund allocation, expansion of health infrastructure, and improved quality and efficiency of health services catering to citizens' needs. ${ }^{68}$

Legal frameworks are key entry points and enabling factors which support participatory and responsive governance. ${ }^{6}{ }^{11}$ In Thailand, the National Health Act 2007 ensures citizen involvement in health decision-making, through participation in the annual National Health Assembly alongside multistakeholders including government agencies, policymakers and academia. ${ }^{12}$ Deliberations and resolutions at the assembly are adopted in consensus and have resulted in the adoption of some legislations such as the Prevention and Solution of the Adolescent Pregnancy Problem Act 2559 BE (2016), ${ }^{13}$ and Cabinet resolutions with legal and enforcement power such as the total ban of chrysotile asbestos. ${ }^{14}$ Legislative provisions on participatory governance embedded in the 1997 Constitution Article 170, and the 2017 Constitution Article 133 promote citizen participation in the 'initiative process' (a form of direct democracy where citizens can propose legislation) through submission of draft Acts for consideration by legislative bodies. ${ }^{15}$ These provisions enabled Thai citizens integral role in driving universal health coverage (UHC), including proposing a citizen-led draft bill on UHC endorsed by 50000 electors, and active participation in the policy formulation process leading to the enactment of the National Health Security Act (NHSA) and ultimately the implementation of UHC in 2002. ${ }^{16}$ Through the adoption of the NHSA, the Universal Coverage Scheme (UCS) was introduced, providing health coverage to those insured by the previous Medical Welfare Scheme for low-income households and socially disadvantaged groups, and the publicly subsidised Voluntary Health Insurance for the informal sector, and additionally extended coverage to $30 \%$ of the population not previously insured. ${ }^{17}$ Together with the Civil Servant Medical Benefit Scheme (CSMBS) and Social Health Insurance (SHI), UCS resulted in the full health coverage of the Thai population ${ }^{17}{ }^{18}$ (see table 1 for a summary of the three schemes).

There are studies on Thai health system reform, ${ }^{19} \mathrm{UHC}$ benefit package ${ }^{20-22}$ impact of UHC on health status, ${ }^{23-25}$ equity $^{2627}$ and financial risk protection ${ }^{28}$; however studies on the legislative provisions and role of participatory and responsive governance in the UHC are still lacking. This study aims to identify, analyse and compare the legislative provisions related to participatory and responsive governance within the three public health insurance schemes (UCS, CSMBS and SHI) constituting UHC in Thailand. Drawing lessons from Thailand can be useful for lowincome and middle-income countries in their legislative process for UHC.

\section{METHODS \\ Conceptual framework}

To guide data collection and analysis, authors developed a conceptual framework derived from available literature. Authors purposively searched on PubMed, and grey literature was obtained through searches of WHO and other relevant UN databases, using search terms including "participation theories, health responsiveness, responsive governance, participatory governance". A total of 340 articles were obtained and screened by authors. Authors selected 13 articles ${ }^{4-1129-34}$ based on relevance to the themes of legislations on citizen participation and responsive governance in health systems through internal discussion, and thematically categorised the information to develop the conceptual framework.

\begin{tabular}{|c|c|c|c|c|c|}
\hline & $\begin{array}{l}\text { Medical Welfare } \\
\text { Scheme }\end{array}$ & $\begin{array}{l}\text { Civil Servant Medical } \\
\text { Benefit Scheme } \\
\text { (CSMBS) }\end{array}$ & $\begin{array}{l}\text { Social Health } \\
\text { Insurance (SHI) }\end{array}$ & $\begin{array}{l}\text { Voluntary Health } \\
\text { Insurance } \\
\text { Scheme }\end{array}$ & $\begin{array}{l}\text { Universal } \\
\text { Coverage } \\
\text { Scheme }\end{array}$ \\
\hline Policy legal framework & Government policy & $\begin{array}{l}\text { Royal Decree on } \\
\text { Medical Benefits of } \\
\text { Civil Servant }\end{array}$ & $\begin{array}{l}\text { Social Security } \\
\text { Act }\end{array}$ & $\begin{array}{l}\text { Government } \\
\text { policy }\end{array}$ & $\begin{array}{l}\text { National Health } \\
\text { Security Act }\end{array}$ \\
\hline Year adopted & 1975-2002 & 1980 & 1990 & 1984-2002 & 2002 \\
\hline Population & $\begin{array}{l}\text { Poor, elderly, children } \\
<12 \text { years and other } \\
\text { underprivileged } \\
\text { groups }\end{array}$ & $\begin{array}{l}\text { Civil servants and their } \\
\text { dependents }\end{array}$ & $\begin{array}{l}\text { Private sector } \\
\text { employees }\end{array}$ & $\begin{array}{l}\text { Non-poor } \\
\text { informal sector }\end{array}$ & $\begin{array}{l}\text { All remaining } \\
\text { populations } \\
\text { not covered by } \\
\text { CSMBS and } \\
\text { SHI }\end{array}$ \\
\hline $\begin{array}{l}\text { Population coverage (\% } \\
\text { of Thai citizens), } 2020\end{array}$ & Not applicable & 6 million (9) & 11 million (16) & Not applicable & 51 million (75) \\
\hline
\end{tabular}




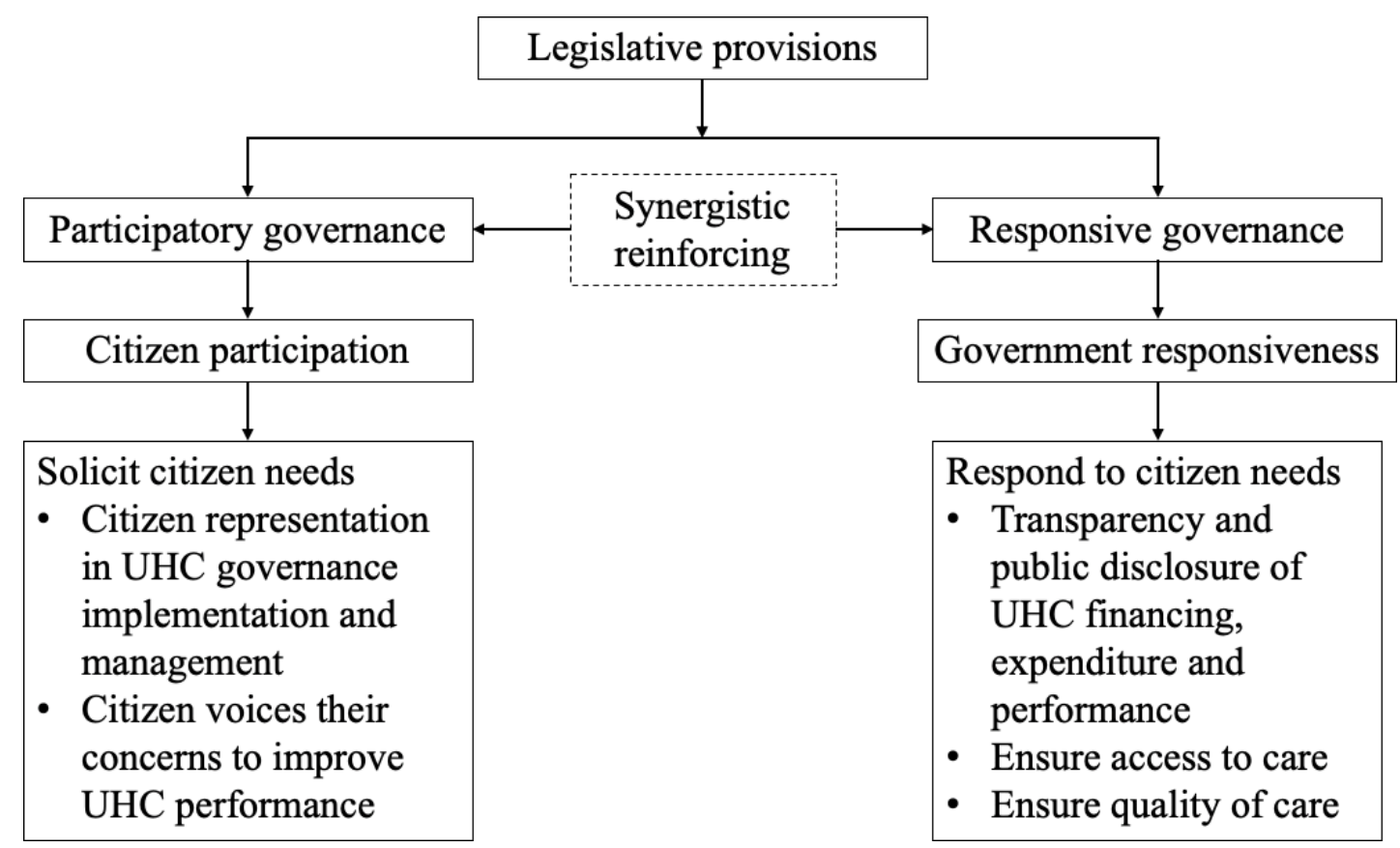

Figure 1 Conceptual framework-synergistic and reinforcing between participatory and responsive governance. UHC, universal health coverage.

\section{Data collection}

The three public health insurance schemes constituting UHC in Thailand are each established and governed through individual laws. ${ }^{35}$ CSMBS was enacted under the Royal Decree on Medical Benefits of Civil Servant (RD-MSCS) 1980, which was amended by the RD-MSCS $2010 .{ }^{35}$ SHI was enacted under the Social Security Act (SSA) 1990, amended by the SSA 2010, and UCS enacted under National Health Security Act (NHSA) 2002. ${ }^{35}$ Each of the three policy documents in the original Thai text was obtained from the Thai Royal Gazette through the Office of the Council of State.

\section{Data analysis}

Using a directed qualitative content analysis based on the conceptual framework in figure 1, each legal document was individually reviewed, and legislative provisions relevant to the conceptual framework were categorised then translated and interpreted in English. Taking the analysis of each individual document, the information was analysed side by side to explore the commonalities and differences across elements based on the conceptual framework.

\section{RESULTS}

\section{Conceptual framework}

Responsive governance aims to meet and adapt to the changing health needs of citizens, and promote and improve accessand quality of health services ${ }^{4629}$ According to the 'WHO Framework for Measuring Responsiveness', responsiveness to citizens aims to protect citizens' dignity, autonomy and confidentiality, ensure prompt attention and quality of services, and enable access to social support networks and choice of provider or facility. ${ }^{30}$ Additionally, responsiveness ensures dissemination and access to public information. ${ }^{4}$

Participatory governance aims to increase citizen participation in public policy processes. ${ }^{46}{ }^{29}$ Involvement of citizens in the decision-making of public services can lead to governance solutions tailored to the needs of the community, ensuring more adaptive and responsive services catering to public demands. ${ }^{6}$ Public involvement can be viewed as a right and duty of citizens to increase democratic decision-making, and right to information and enhance accountability and responsiveness; as a result improve governance of public services and make government's decisions more transparent and equitable. ${ }^{6-8} 1031$

Citizen participation in health decisions can contribute to enhanced information of citizen preferences on government decisions to increase equity in health through identifying social determinants based on community knowledge and addressing the root causes of inequity to improve access and quality of services and allow citizens better understanding of the health system for more effective use of public services. ${ }^{68}{ }^{32}$ Participatory governance increases government responsiveness as it reduces the conflicts between the agent (the government) and principals (the citizens who elect the government) through proper incentive structure for the agent, bidirectional information flows, and minimise the discretion power of the agent when citizens are included in the decision-making. ${ }^{6}$ Reciprocally, studies have found that effective government responsiveness to citizens encourages greater participation and promotes outcomes of participatory governance. ${ }^{33}$ Government responsiveness 
requires public participation and engages citizens in decision-making, policy-making, implementation, monitoring and evaluation processes to guide development centred on people's needs and well-being, ${ }^{4}$ through deliberations and spaces for consensus. ${ }^{44}$ Therefore, public participation and engagement in governance are an important prerequisite for government responsiveness, and vice versa, responsive governance enables civic participation and provides policy spaces for engagement by citizens. Both synergistically ensure the needs of citizens are met. ${ }^{4}$ This is depicted by double-headed arrow between responsive governance and citizen participation (figure 1), where participatory governance increases government responsiveness and government responsiveness to citizens encourages greater participation. ${ }^{633}$

\section{Participatory governance}

Citizen representation and involvement in UHC governance, implementation and management

In the UCS, 10 provisions (NHSA Sections 13, 17, 18, 19, $21,41,42,47,48,50)$ ensure citizen representation and involvement. The 30-member governing body of UCS, the National Health Security Board (NHSB), must consist of five citizens. Citizens are selected among themselves from the nine civil society organisation (CSO) constituencies registered with the Ministry of Interior whose works are related to (1) children and adolescents; (2) women, (3) elderly, (4) disabled and mentally ill patients, (5) patients with HIV and chronic disease, (6) labour, (7) slum, (8) agriculture and (9) minorities. Each board member is allocated one vote, with decisions made based on majority: providing citizens with $17 \%$ (5 out of 30 ) of the board's voting power. The board directs and oversees the performance of the management and the operation of the scheme. This gives citizens the power to influence decisions on the standards and scope of health services, appointment of the secretary general to effectively implement the scheme, regulations and approval of administrative policies, financial plans, annual budget ceiling and other relevant governance matters. The board also ensures transparency and accountability of the scheme's governance to citizens, with the duty to ensure the scheme is suitable and responds to the needs of different populations across the country, by supporting and coordinating with local government organisations. Citizens are also represented in the scheme's Standard and Quality Control Board (QSB). Similar to the NHSB, the 35-member QSB must consist of five citizen representatives $(14 \%)$, selected from the same nine CSO constituencies. Through this board, citizens via their CSO members, can indirectly influence decisions on the quality of care, make decisions on complaints, audit quality of care and decide on payments for no-fault financial assistance to patients experiencing adverse events from medical treatment to directly meet the needs of citizens.

In the SHI scheme, Section 8 of the 2015 amendment, as well as Sections 9 and 13, are relevant to citizen representation and involvement. The 21-member Social Security
Committee must consist of seven members representing employers and seven members representing employees; while the remaining seven are ex-officios from the government. Citizen representatives in the committee are appointed by the Ministry of Interior based on the results of an election fully participated by employees, men and women, as well as disabled and disadvantaged populations. Each committee member has one vote with decisions made based on majority, giving employees $33 \%$ (7 out of 21) of the voting power. Through representation in the committee, employees have the ability to influence the decisions on regulations, policy, implementation, finances, budgetary decisions and expenses of the scheme.

\section{Citizens' ability to voice concerns and improve UHC}

There are five provisions relevant to citizens' ability to voice concerns in the NHSA (Sections 18, 26, 50, 57-60) and one provision (Section 85) in the SSA.

The NHSB and QSB in UCS have the duty to facilitate citizens in lodging complaints and citizens are entitled to file against health facilities that do not comply with standards set for its members. This includes inadequacy of the facility in responding to citizen needs and adverse events from medical treatment. The National Health Security Office (NHSO), responsible for managing the scheme, is directly mandated to handle citizens' complaints and take action. Similarly, for SHI, beneficiaries are entitled to voice concerns by filing complaints if dissatisfied with decisions on the scheme.

NHSA also mandates UCS's boards to improve the quality and standard of health services based on the needs of citizens through gathering opinions from citizens, by holding annual public hearings with both service providers and citizen beneficiaries.

\section{Responsive governance}

Enable access to information

The Act governing UCS encourages citizens access to information on the scheme's governance. Sections 26 and 43 of the Act mandate public disclosure of the annual performance, budget execution and annual budget utilisation. The NHSO is required to produce and publicly disseminate annual reports on the performance and operational obstacles, as well as publish financial documents reported by the boards related to revenue and use of the National Health Security Fund in the Royal Gazette, which is publicly available. These provisions demonstrate transparency and responsiveness to members in ensuring access to information to further empower citizens with knowledge to better actively participate in the scheme's governance and ensuring its transparency.

Both UCS and SHI schemes ensure access to information on health services and facilities to increase responsiveness to citizens' needs on health facility options and autonomy in making decisions on their facility or treatment of choice, as mandated in NHSA Sections 26, 44, 45 and 50, and SSA Section 59. 
In UCS, the QSB must develop an information dissemination system to ensure access to relevant information on health services, and NHSO must publicise information regarding health service facilities to ensure citizens can make informed decisions. Health facilities are also required to provide accurate information on the diagnosis, treatment and alternative options to safeguard citizen autonomy in making decisions on their health and treatment choice.

In SHI, the information on the location and name of health facilities, which members can avail services, must be publicly available through publication in the government gazette.

\section{Enable access to care}

Ensuring access to care is mandated in the NHSA Sections 6-8, 26, 38 and 44, SSA Section 59 and RD-MSCS Sections $8,13,16$ and 17 .

In UCS, the 'National Health Security Fund' aims to pay for health services and allocates resources to strengthen health facilities in geographical areas with inadequate health facilities. The fund allows for improvements of supply side capacity that facilitate access to healthcare in disadvantaged areas.

For UCS members, the NHSO is required to register all members with a provider network of their choice, including on-site registration at the first use of services, for those who have not registered and immediately entitling them to health services; which indicates responsiveness to citizens' need for prompt attention to care for those not yet registered but in need of healthcare. The Act also facilitates re-registration to different facilities to enable changes in residence or temporary migration such as for seeking jobs outside their domicile district, ensuring continued rights to health services. For accident and emergency cases, members are also covered at any nearest health provider, further supporting responsiveness to citizens' prompt attention to access to care.

Similarly, SHI members are also entitled to their choice in health facility and changing of health facility of choice.

In contrast, civil servants under CSMBS require no registration to a health facility, but are entitled to their choice of any government hospital. Civil servants also have the ability to choose private facilities for accidents and emergencies or when government hospitals are unable to provide adequate care and therefore must transfer patients to a private facility. Additionally, healthcare costs for civil servants working or studying in foreign countries are also reimbursable by the scheme, ensuring prompt attention to health services based on the needs of members.

\section{Ensure quality of care}

Legislative provisions in the NHSA (Sections 5, 18, 26, $41,42,45,50$ and 57-60) and SSA (Section 63), and the RD-MSCS (Section 13) ensure provisions of care are responsive to citizens' need for standard quality of care.
UCS members are ensured the right to quality health as the QSB and NHSO are mandated to set standards and ensure health services adhere to standards to meet citizen needs. Facilities are required to ensure prompt attention to services, protect and respect members' dignity, grant access to social needs and maintain confidentiality. The boards are mandated to investigate any complaints made by members on facilities that are unable to meet citizen's needs. If facilities are found to be incompliant, the boards may issue warnings to respect members' rights and benefits or take disciplinary actions, such as de-listing these health facilities from the UCS systems or legal actions against the facilities. The NHSB is also mandated to earmark not more than $1 \%$ of the National Health Security Fund for an initial 'no-fault' financial assistance to patients experiencing adverse events from medical interventions. Members who have been damaged by health services can be compensated, to minimise the pain and suffering resulting from the loss of life, disability or morbidity. Similarly, SHI members are also entitled to no-fault compensation for adverse events from medical services to protect members' needs to quality and standard health services.

For CSMBS, as choice of healthcare facilities are at the discretion of civil servants, where members are free to use any public facilities, including tertiary and specialist hospitals, members are able to seek facilities they deem to have the best quality care. In cases where a public health facility is unable to provide certain services, beneficiaries are also entitled to services at private health facilities and be reimbursable by the scheme.

\section{Variations across schemes}

Table 2 summarises legal provisions related to participatory and responsive governance across three insurance schemes.

Participatory governance is implemented in the form of citizen representation in the management of the schemes as well as ability to voice concerns to improve the schemes for both UCS and SHI. In contrast, the legal provisions in the RD-MSCS do not propose a governing body or member representation in the governing body for the management of the CSMBS or empower citizen voice.

All four policies consist of responsive governance provisions. All schemes are governed by provisions on citizens' access to care. In UCS and SHI, the access is granted through ensuring registration to health facility of choice and ability of re-registration when needed, while civil servants are granted access to any public facility of choice and private facilities in specific circumstances. Choice in health facility also serves to ensure civil servants access quality care, while quality and standard of care is explicitly mandated for health facilities under UCS with the board able to take action for incompliance. Additionally, UCS and SHI members are entitled to no-fault compensation and ensure citizens' access to information. However, there are no such 
Table 2 Summary and comparison of legislative provision related to participatory and responsive governance across three insurance schemes

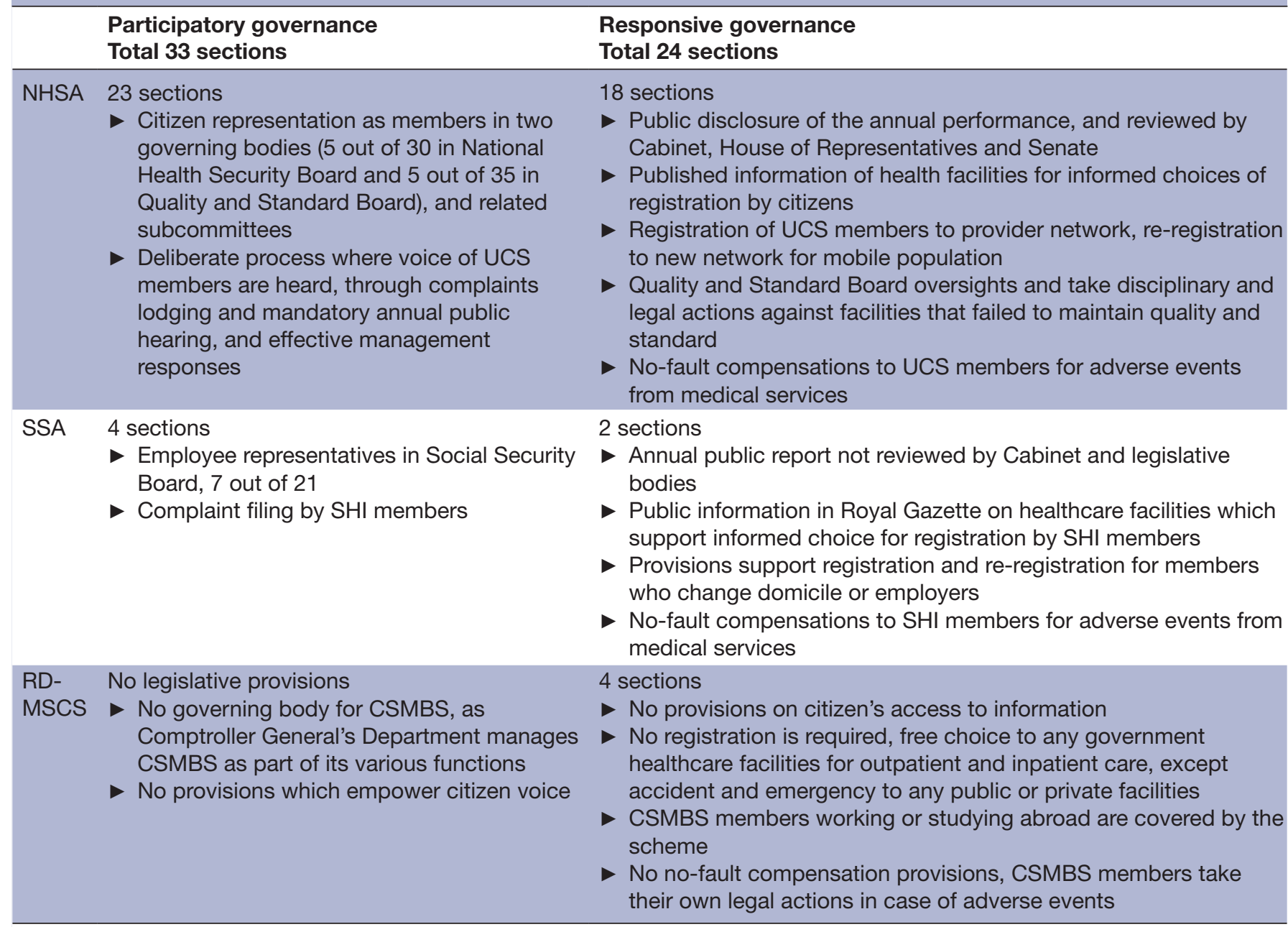

CSMBS, Civil Servant Medical Benefit Scheme; NHSA, National Health Security Act; RD-MSCS, Royal Decree on Medical Benefits of Civil Servant; SHI, Social Health Insurance; SSA, Social Security Act; UCS, Universal Coverage Scheme.

provisions in the RD-MSCS for civil servants; members are not ensured access to health information and must take their own legal action in case of adverse events.

\section{DISCUSSION}

Legislative provisions on participatory and responsive governance play an important role in ensuring citizen participation and government responsiveness to citizens in Thailand's UHC. As Thai UHC is implemented through three public insurance schemes, the extent to which beneficiaries can actively participate in the scheme's management and obligations of the schemes in responding to its members' needs highly vary. The NHSA consists of the most sections related to participatory and responsive governance; with 23 sections on participatory and 18 on responsive governance, while five sections (Sections 18, 26, 47, 50 and 59) overlap between the two themes. Box 1 summarises key lessons on participatory and responsive governance for the UCS in Thailand. The SSA consists of the second greatest number of legal provisions on participatory governance with four sections on participatory and two provisions on responsive governance. The RD-MSCS consists of no sections related to participatory governance, and four related to responsive governance. Online supplemental file 1 (available from website) summarises each legislative provision and its interlinks with citizen participation and government responsiveness.

The variations in the insurance scheme are directly related to the involvement and participation of citizens in the initiation and development process of the legislations. Further, the scope of this study covers the analysis of legislative provisions, which are merely enabling factors for responsive and participatory governance. The implementation capacities of each scheme and their commitment are vital in ensuring citizen participation and government's responsiveness to citizens' needs. ${ }^{6}$

\section{Contributions of citizens in UHC legislative process}

The majority of participatory and responsive governance provisions in the Thai UHC are found in the NHSA. This is a direct result of the active engagement of citizens 
Box 1 Key lessons on participatory and responsive governance for Universal Coverage Scheme in Thailand

- The forward-looking legislative provisions in the National Health Security Act, as a result of citizen participation in the legislative process, are key enabling factors for participatory and responsive governance.

- Citizen participation through civil society organisation representatives in the governing board, the Quality Board and other subcommittees of the boards of the Universal Coverage Scheme ensures responsiveness of the scheme to citizens' needs. Voice and concerns raised at the annual public hearing have received policy and management responses for performance improvement.

- Responsive governance is demonstrated by public disclosure of the annual performance report which is made publicly available; enabling access to care through registration of members to a preferred healthcare facility network and re-registration as needed in particular temporary changes of address; and ensuring provision of quality care and initial financial support for adverse events.

- The implementation capacity and sustained commitment by National Health Security Office is a key factor in the successful translation of these legislative provisions into reality.

in the Act's legislative process. The contents of the Act originate from CSOs' proposed draft bill, submitted to the legislative body with endorsement from over 50000 eligible voters. ${ }^{36}{ }^{37}$ At the first reading in the House of Representatives, the draft bill was accepted in principle, and five civic group representatives were appointed as members of the parliamentary committee to review and amend the contents in the draft bill article by article in its second reading. ${ }^{38}$ Civic group representatives played an active role in the second reading to negotiate the bill's contents, where the draft bill was finalised then endorsed at the third reading of the House of Representatives. ${ }^{16}$ In contrast, there was neither active engagement by CSOs in legislating the 1990 SSA and its amendment in 2010, nor engagement of civil servants when the RD-MSCS was adopted in 1980.

\section{Citizen participation in UHC governance}

Study on citizen participation in the Thai UCS found that citizens have actively participated in governance decisionmaking through representation in the UCS boards, and ensured actions on local problems were taken including policy decisions and management responses to rectify the gaps and increase effectiveness and responsiveness of the scheme. ${ }^{39}$ The SHI also has citizen representatives in the governing body. The SSA's 2010 amendment further increased citizen participation by selecting employee representatives through an election instead of selection by the Ministry of Interior, increasing transparency, as well as gender equity and participation of disabled and disadvantaged persons. Although there are no provisions in which entitle civil servants to be presented in the governing body of the CSMBS, the Civil Service Association, which protects the rights and benefits of civil servants including medical benefits, can voice for members. The association has been successful in voicing for members, including the case of reimbursement for glucosamine. ${ }^{40}$

Although only the NHSA mandates facilitation of complaint lodging, two other schemes have implemented complaint-handling systems. UCS operates the $24 / 7$ call centre '1330' and supports local CSO complaint centres, as well as the Ministry of Public Health established UCS units at hospitals which support patients in navigating services and resolve conflicts between providers and patients. ${ }^{41}{ }^{42}$ In 2018, the ' 1330 ' call centre received 5248 complaints regarding health facilities, of which $76.01 \%$ were addressed within 25 days. ${ }^{43}$ The Social Security Office similarly implemented a $24 / 7$ hotline ' 1506 ' in 2016, as well as live chat services on the website in order to allow SHI members to ask questions and lodge complaints. ${ }^{44}$ Comptroller General's Department, which manages the civil servant's scheme, also operates a call centre; however, it is not exclusive for CSMBS but for all consultations related to the function of the department.

The UCS has also implemented provisions on public hearings to gather opinions from citizens by hosting annual hearings for both service providers and UCS members at the provincial, regional and national levels. ${ }^{41}$ A study found that the public hearings have been successful in influencing policy decision-making ${ }^{45}$ and resulted in the development and expansion of the scheme's benefit package, including establishment of the Rehabilitation Fund in 2004, authorisation of re-registration with new provider networks up to four times a year in 2012, and termination of restrictions which limit the number of gestations per woman entitled to maternity services in $2015 .^{46}$

\section{UHC responsiveness to citizens}

Through responsive governance, insurance agencies ensure (a) citizens' access to information in a transparent manner, (b) access to health services and (c) access to quality of care. Ensuring access to information, the NHSO publishes annual performance and financial reports, publicly available on the NHSO website detailing National Health Security System performance, management of services, expenses and quality control, as well as complaints and satisfaction of health services. ${ }^{47}$ The audited financial reports are also submitted to the Cabinet, the Parliament and the Senate for accountability, as the UCS is fully financed by general tax through annual budget allocation. The Social Security Office also publishes an annual report, publicly available on its website, though they are not required to report to the executive and legislative bodies. ${ }^{48}$ In contrast, despite being publicly financed, the RD-MSCS does not require the Comptroller General's Department to produce publicly available annual reports on CSMBS performance.

Access to health services is guaranteed for all schemes. Civil servants have access to any of the 11959 public health providers across the country. ${ }^{49}$ UCS members are able to 
register with one of the approximately 12000 public and private health service units registered with the NHSO across the country ${ }^{43}$ with the ability to change registration of their health provider up to four times annually at facilities or via mobile application. ${ }^{50} 51$ SHI members can register to one of the 163 public and 79 private main contracting health units available, and are able to change their health provider once annually between 1 January and 31 March at the local Social Security Office, via their website or mobile application. ${ }^{52}{ }^{53}$ Change of provider during the year is also possible for members who have moved to a new workplace or relocated.

In order to safeguard quality of health services, all public and private hospitals in Thailand need to meet national standardised assessments set by the Health Care Accreditation Institute (HAI) (public organisation).$^{54} \mathrm{In}$ addition, the NHSO conducts annual service unit inspections to assess all facilities based on nationally set standards and guidelines developed in collaboration with the Ministry of Public Health and relevant stakeholders; in 2019 over $90 \%$ of all units passed inspections. ${ }^{435}$ The office also conducts unannounced health facility visits, for those suspected to be non-compliant based on complaints and random checks with citizens. The Social Security Office similarly conducts assessments of facilities; annually for private facilities and every 2-3 years for public facilities. In addition, health facilities covering SHI members must also be accredited through the Joint Commission International or Thailand HAI. ${ }^{56}{ }^{57}$ The Comptroller General's Department does not conduct assessments, but instead uses the outcomes assessed by NHSO inspections and accreditation status by the HAI for hospitals providing services to civil servants.

A few strengths of this paper are identified. This paper demonstrates how participatory governance increases government responsiveness and reciprocally effective government responsiveness to citizens encourages greater participation and promotes outcomes of participatory governance; both of which have advanced towards a high-performing UCS. Further, the paper highlights the implementation capacity which is equally important as the legislative provisions. However, the design of this study does not allow in-depth understanding of the policy dynamics and conflicts between CSO representatives and ex-officio members in the governing board and QSB, as well as conflicts resolution in advancing the UCS performance.

\section{CONCLUSION}

Comprehensive legislative provisions which cover two synergistic virtues, namely support of citizen participation and enabling government responsiveness, are critical to ensure citizens' needs and concerns are taken into account when implementing UHC. Responsive governance provides policy spaces for citizen participation, and in turn citizen participation results in responsive governance. Legislative provisions should be accompanied with adequate implementation capacity and sustained commitment.

Citizens and civil society engagement in legislative process of NHSA through the 'initiative process' marks the legislation in history. There was no such engagement for the legislative process of the SSA and its amendments or RD-MSCS.

In the quests for UHC, low-income and middle-income countries can draw lessons on how citizens contribute to the legislative process in ensuring provisions related to participatory and responsive governance are in the law. The implementation of these provisions by Thailand's UHC has proven that legislative provisions are as equally important as the implementation capacity. Further, we found the framework generated from this study is simple, practical and could be applied elsewhere.

Contributors VT, AIM, KK and WP jointly designed the study. VT, AIM, KK, KK and $\mathrm{SC}$ conducted the analysis. AIM wrote up the first draft of this article. VT, AIM and KK finalised the article. All agreed with the final version for submission.

Funding The authors gratefully acknowledge the funding support from WHO Southeast Asia Regional Office through the management of WHO-Thailand and the funding support through the International Health Policy Program (IHPP) from the Thailand Science Research and Innovation (TSRI), under the Senior Research Scholar on Health Policy and System Research (contract no. RTA6280007).

Competing interests None declared.

\section{Patient consent for publication Not required.}

Ethics approval Ethics approval was granted by the Institute for the Development of Human Research Protection, Thailand. The ethics approval number is COA No. IHRP2019095 (dated 28 0ctober 2019).

Provenance and peer review Not commissioned; externally peer reviewed.

Data availability statement All data relevant to the study are included in the article or uploaded as supplemental information. All data used in this paper are publicly available or included in the article.

Supplemental material This content has been supplied by the author(s). It has not been vetted by BMJ Publishing Group Limited (BMJ) and may not have been peer-reviewed. Any opinions or recommendations discussed are solely those of the author(s) and are not endorsed by BMJ. BMJ disclaims all liability and responsibility arising from any reliance placed on the content. Where the content includes any translated material, BMJ does not warrant the accuracy and reliability of the translations (including but not limited to local regulations, clinical guidelines, terminology, drug names and drug dosages), and is not responsible for any error and/or omissions arising from translation and adaptation or otherwise.

Open access This is an open access article distributed in accordance with the Creative Commons Attribution Non Commercial (CC BY-NC 4.0) license, which permits others to distribute, remix, adapt, build upon this work non-commercially, and license their derivative works on different terms, provided the original work is properly cited, appropriate credit is given, any changes made indicated, and the use is non-commercial. See: http://creativecommons.org/licenses/by-nc/4.0/.

\section{ORCID iD}

Aniqa Islam Marshall http://orcid.org/0000-0001-6575-731X

\section{REFERENCES}

1 Murray CJ, Frenk J. A framework for assessing the performance of health systems. Bull World Health Organ 2000;78:717-31.

2 World Health Organization. The world health report 2000. Geneva: World Health organization, 2000.

3 Malhotra R, Taneja O, Dhingra V. Awareness regarding tuberculosis in a rural population of Delhi. Indian Journal of Community Medicine 2002;27.

4 Department of Economic and Social Affairs, United Nations. World public sector report: responsive and accountable public governance. United nations, 2015. Available: https://publicadministration.un. 
org/publications/content/PDFs/World\%20Public\%20Sector\% 20Report2015.pdf

5 International Conference on primary health care Declaration of AlmaAta. WHO Chron 1978;32:428-30.

6 Speer J. Participatory governance reform: a good strategy for increasing government responsiveness and improving public services? World Dev 2012;40:2379-98.

7 Florin D, Dixon J. Public involvement in health care. BMJ 2004;328:159-61.

8 Wait S, Nolte E. Public involvement policies in health: exploring their conceptual basis. Health Econ Policy Law 2006;1:149-62.

9 Stewart E. What is the point of citizen participation in health care? J Health Serv Res Policy 2013;18:124-6.

10 Conklin A, Morris Z, Nolte E. What is the evidence base for public involvement in health-care policy?: results of a systematic scoping review. Health Expect 2015;18:153-65.

11 McGee R. Legal frameworks for citizen participation: synthesis report. Sao Paulo: Learning Initiative on Citizen Participation and Local Governance (Logolink), 2003. https://gsdrc.org/documentlibrary/legal-frameworks-for-citizen-participation-synthesis-report/

12 Rajan D, Mathurapote N, Putthasri W, et al. Institutionalising participatory health governance: lessons from nine years of the National health assembly model in Thailand. BMJ Glob Health 2019;4:e001769.

13 Rasanathan K, Posayanonda T, Birmingham M, et al. Innovation and participation for healthy public policy: the first National health assembly in Thailand. Health Expect 2012;15:87-96.

14 Kanchanachitra C, Tangcharoensathien V, Patcharanarumol W, et al. Multisectoral governance for health: challenges in implementing a total ban on chrysotile asbestos in Thailand. BMJ Glob Health 2018:3:e000383.

15 Constitution of the Kingdom of Thailand. Somdet phra paramintharamaha bhumibol adulyadej sayammintharathirat borommanatthabophit, 2017. Available: http://web.krisdika.go.th/ data/outsitedata/outsite21/file/Constitution_of_the_Kingdom_of Thailand.pdf

16 Pitayarangsarit $\mathrm{S}$. The introduction of the universal coverage of health care in Thailand: policy responses [PhD Thesis]. London, United Kingdom, London School of Hygiene \& Tropical Medicine, 2005. https://researchonline.Ishtm.ac.uk/id/eprint/682331/

17 Tangcharoensathien V, Witthayapipopsakul W, Panichkriangkrai W, et al. Health systems development in Thailand: a solid platform for successful implementation of universal health coverage. Lancet 2018;391:1205-23.

18 Tangcharoensathien V, Patcharanarumol W, Kulthanmanusorn A, et al. The political economy of UHC reform in Thailand: lessons for low- and middle-income countries. Health Syst Reform 2019;5:195-208

19 Wibulpolprasert S, Thaiprayoon S. Thailand: good practice in expanding health coverage - lessons from Thai health care reform. Good practices in health financing 2008:355-84

20 Mohara A, Youngkong S, Velasco RP, et al. Using health technology assessment for informing coverage decisions in Thailand. J Comp Eff Res 2012:1:137-46.

21 Teerawattananon Y, Tangcharoensathien V. Designing a reproductive health services package in the universal health insurance scheme in Thailand: match and mismatch of need, demand and supply. Health Policy Plan 2004;19 Suppl 1:i31-9.

22 Youngkong S, Baltussen R, Tantivess S, et al. Multicriteria decision analysis for including health interventions in the universal health coverage benefit package in Thailand. Value Health 2012;15:961-70.

23 Patcharanarumol W, Tangcharoensathien V, Limwattananon S. Why and how did Thailand achieve good health at low cost? In: Good health at low cost' 25 years on. What makes a successful health system? London School of Hygiene \& Tropical Medicine 2011:193-223.

24 Suraratdecha C, Saithanu S, Tangcharoensathien V. Is universal coverage a solution for disparities in health care? Health Policy 2005;73:272-84

25 Tangcharoensathien V, Tantivess S, Teerawattananon Y, et al. Universal coverage and its impact on reproductive health services in Thailand. Reprod Health Matters 2002;10:59-69.

26 Prakongsai P, Limwattananon S, Tangcharoensathien V. The equity impact of the universal coverage policy: lessons from Thailand. Adv Health Econ Health Serv Res 2009;21:57-81.

27 Limwattananon S, Tangcharoensathien V, Prakongsai P. Equity in maternal and child health in Thailand. Bull World Health Organ 2010;88:420-7.

28 Tangcharoensathien V, Tisayaticom K, Suphanchaimat R. Financial risk protection of Thailand's universal health coverage: results from series of national household surveys between 1996 and 2015. Int $J$ Equity Health 2020;19:163.

29 Mirzoev T, Kane S. What is health systems responsiveness? review of existing knowledge and proposed conceptual framework. $B M J$ Glob Health 2017;2:e000486.

30 Silva A. A framework for measuring responsiveness. EIP/GPE/ EBD, 2010. Available: https://www.who.int/responsiveness/papers/ paper32.pdf?ua $=1$

31 World Health Organization. Towards a global action plan for healthy lives and well-being for all 2018.

32 Brown C, Harrison D, Burns H. Governance for health equity: in the WHO European region. updated reprint 2014. Copenhagen, Denmark: World Health Organization Regional Office for Europe, 2014.

33 Sjoberg FM, Mellon J, Peixoto T. The effect of bureaucratic responsiveness on citizen participation. Public Adm Rev 2017;77:340-51.

34 WHO Regional Office for Europe. Participation as a driver of health equity. Copenhagen, 2019. Available: https://apps.who.int/ iris/bitstream/handle/10665/324909/9789289054126-eng.pdf? sequence $=1$ \&isAllowed $=\mathrm{y}$

35 World Health Organization. Regional office for the Western Pacific. The Kingdom of Thailand health system review, 2015. Available: http://iris.wpro.who.int/handle/10665.1/11359

36 Ravenscroft J, Marcos L. Civil society organisations and universal health care. The Lancet 2012;380:888.

37 Rosenquist R, Golichenko O, Roosen T. A critical player: the role of civil society in achieving universal health coverage. Glob Health Gov 2013;6:2.

38 Royal Thai Government Gazette. Announcement of the house of representative: appointment of the ad-hoc Committee to consider draft National health security act B.E, 2001. Available: http://www. ratchakitcha.soc.go.th/DATA/PDF/00088492.PDF

39 Kiewnin K, Chotchoungchatchai S, Kantamaturapoj K. Citizen participation in governing Thailand's Universal Health Coverage Scheme. 2020;14:274-88.

40 Tantivess S, Tangcharoensathien V. Coverage decisions and the court: a public health perspective on glucosamine reimbursement in Thailand. Health Syst Reform 2016;2:106-11.

41 Kantamaturapoj K, Kulthanmanusorn A, Witthayapipopsakul W, et al Legislating for public accountability in universal health coverage, Thailand. Bull World Health Organ 2020;98:117-25.

42 National Health Security Office. Customer right protections under the universal coverage scheme (UCS) in Thailand. Thailand: National Health Security Office; 2019. http://eng.nhso.go.th/ assets/portals/1/files/02\%20UCS\%20Consumer\%20Protection. pdf

43 National Health Security Office. NHSO annual report 2018, 2018. Available: https://www.nhso.go.th/FrontEnd/page-contentdetail. aspx?CatID=MTA5NQ==

44 Ministry of Labour. Social security Hotline 1506 full service with advice and inquiries, 2017. Available: https://www.mol.go.th/en/ news/social-security-hotline-1506-full-service-with-advice-andinquiries-2/

45 Kantamaturapoj K, Marshall Al, Chotchoungchatchai S, et al. Performance of Thailand's universal health coverage scheme: evaluating the effectiveness of annual public hearings. Health Expect 2020;23:1594-602.

46 National Health Security Office. People's Participation of the universal coverage scheme (UCS) in Thailand. Thailand: National Health Security Office; 2019. http://eng.nhso.go.th/assets/portals/1/ files/05\%20UCS\%20PublicParticipation.pdf

47 NHSO. NHSO annual reports, 2020. Available: http://eng.nhso.go.th/ view/1/Annual_Reports/EN-US

48 Social Security Office. Annual report, 2020. Available: https://www. sso.go.th/wpr/main/privilege/\%E0\%B8\%A3\%E0\%B8\%B2\%E0\% B8\%A2\%E0\%B8\%87\%E0\%B8\%B2\%E0\%B8\%99_sub_category_ list-label_1_130_716

49 Ministry of Public Health. Geographic information system on health, 2019. Available: http://gishealth.moph.go.th/healthmap/gmap.php

50 Royal Thai Government Gazette. Regulations of the National health security board: regarding the criteria, methods, and conditions for registration, and requesting to change a service unit, 2019. Available: http://www.ratchakitcha.soc.go.th/DATA/PDF/2562/E/162/ T 0060.PDF

51 National Health Security Office. NHSO developed an application for universal coverage scheme members to change service units via mobile phones, 2020. Available: https://www.nhso.go.th/FrontEnd/ NewsInformationDetail.aspx?newsid=Mjg1NA==

52 Social Security Office. List of hospitals under social security schemes for the year 2020 by Province, 2020. Available: https:// 
www.sso.go.th/wpr/assets/upload/files_storage/_th/b2a2b67b97d4 19a5e0fc91574c370bbb.pdf

53 Social Security Office. Changing services unit under the social security schemes, 2020. Available: http://www.gcc.go.th/webgcc/? $\mathrm{p}=3111$

54 Royal Thai Government Gazette. The Royal decree on the establishment of the healthcare accreditation Institute (public organization), B.E. 2552, 2009. Available: http://www.ratchakitcha. soc.go.th/DATA/PDF/2552/A/041/17.PDF

55 National Health Security Office. National health security office annual report 2017, 2017. Available: http://stream.nhso.go.th/ wp-content/uploads/ebooks/annual-2017/\#page $=5$ [Accessed 18 Sep 2020].

56 Royal Thai Government Gazette. Announcement of the socia security office: standards for services unit under the social security schemes, 2020. Available: http://www.oic.go.th/FILEWEB/ CABINFOCENTER2/DRAWER056/GENERAL/DATA0000/00000590. PDF

57 Royal Thai Government Gazette. Regulations of the social security office: Disbursement of medical services cost to health facilities and disbursement of drug cost to government agencies, 2016. Available: http://www.ratchakitcha.soc.go.th/DATA/PDF/2559/E/197/7.PDF 